\title{
The Examination of Factors Influencing Saudi Small Businesses' Social Media Adoption, by Using UTAUT Model
}

\author{
Abeer Bin Humaid ${ }^{1} \&$ Yasser M. Ibrahim ${ }^{1,2}$ \\ ${ }^{1}$ E-business, Management Information System Department, College of Business Administration, King Saud \\ University, Saudi Arabia \\ ${ }^{2}$ Socio-Computing Department, Faculty of Economics and Political Science, Cairo University, Egypt \\ Correspondence: Abeer Bin Humaid, E-business, Management Information System Department, College of Business \\ Administration, King Saud University, Saudi Arabia.
}

Received: February 13, 2019

Accepted: March 5, 2019

Online Published: March 7, 2019

doi:10.5430/ijba.v10n2p96

URL: https://doi.org/10.5430/ijba.v10n2p96

\begin{abstract}
Social media is becoming a major development in electronic commerce among a wide range of sectors, for example, education, government, health care, and business. In Saudi Arabia, a major movement toward social media has taken place, especially among small business entrepreneurs, due to its low cost and the powerful role it can play in globalization.

The goal of this paper is to add to the theoretical knowledge base regarding the adoption of social media among Saudi small businesses, by applying the Unified Theory of Acceptance and Use of Technology (UTAUT) model to examine the influences of Saudi small businesses' social media adoption. An empirical study was carried out using online survey research among 73 Saudi business entrepreneurs. The major findings of the paper are that Saudi small business entrepreneurs tend to use social media for the major constructs of performance expectancy, effort expectancy, social influence, and facilitating conditions. However, although the moderator of gender proved to be effective on the construct of effort expectancy, the effects of the moderators of age, gender, and experience on the other major constructs were not salient.

It is believed that the findings will be useful for understanding adoption phenomena better, to help business entrepreneurs to make superior decisions based on them.
\end{abstract}

Keywords: social media, small business, UTAUT model, Saudi Arabia, performance expectancy, effort expectancy, social influence, facilitating conditions, behavioral intention

\section{Introduction}

Social media is an emerging technology that has been extensively used especially in Saudi Arabia. Statistically, Saudi Arabia has recorded the highest Twitter penetration in the world: $47 \%$ of the total number of Arab tweets are produced in Saudi Arabia (Pownall, 2016). In addition, in 2016, the highest number of views on YouTube came from Saudi Arabia. In business, social media enables and supports information sharing, communicating, and collaboration. This allows businesses to accelerate their work by working in global markets. This power has played a significant role in the growth of small businesses. In addition, social media-for example, Twitter, Instagram, and Facebook - enables small businesses to behave as large companies in terms of attracting customers, increasing sales, building customer relationships, and expanding by selling new products and services (AlHusain and Mirza, 2015). In Saudi Arabia, and with the rise of Saudi Vision 2030 (2016), small businesses are considered an important agent of Saudi economic growth. Supporting these small businesses in competing both domestically and globally is critical.

\subsection{Research Problem}

Social media adoption plays a significant role in economic development. Yet, many small businesses do not believe that they could expand their market and reach customers on social media sites, especially in developing countries such as Saudi Arabia. Saudi government, with the rise of Saudi Vision, aimed to support small businesses with business-friendly regulations, facilitate funding's, and international partnerships. This creates a huge opportunity to small businesses and help the wide spread of them. 
Considering the rapid and extensive use of social media in Saudi Arabia, this research study was aimed at identifying small business entrepreneurs' social media adoption. The goal was also to determine the level of effectiveness of its use. The research study may help with addressing the limitations that need to be solved to overcome barriers to building successful businesses.

\subsection{Research Questions}

- What influences Saudi small businesses' social media adoption?

- How do small business entrepreneurs use social media?

- What are the advantages of using social media?

- What limitations are addressed by using social media?

\subsection{Research Objectives}

The conceptual framework of the Unified Theory of Acceptance and Use of Technology (UTAUT) was proposed as the foundation for this research. The study involved examining direct determinants-performance expectancy, effort expectancy, social influence, and facilitating conditions - along with moderated determinants, including gender, age, experience, and voluntariness. Because this area has not been covered well in Saudi Arabia, this research study introduces a basic framework for building successful small businesses that will contribute to the decision support system process.

\section{Literature Review}

\subsection{Social Media in Business}

According to studies on small businesses' social media adoption, the adoption of social media varies in terms of the various business' requirements, their limitations, and the level of benefit that the adopted technology offers. Using social media in businesses has drawn major attention recently. However, not enough research has covered this subject in the Saudi context.

A major movement toward social media use for business purposes has taken place (Sorensen and Shklovski, 2011). This is the result of today's new generation of smartphones and tablets, which have made buying and selling products and services online easy. According to a Business Intelligence Journal report, approximately $29 \%$ of US mobile users have conducted purchases using their smartphones (2013). As a result, businesses have become more interested in investing money and time into learning how to generate profits from social media applications, for example, Facebook, Twitter, Instagram, and Snapchat. Businesses' adoption of social media has facilitated businesses' communication with their customers as well as with other businesses. These applications are generally free, are easy to use, and feature content that is user generated (Serben, 2014).

\subsection{Small Businesses}

Small businesses are often described as fuel for economic growth in all countries. Electric commerce (e-commerce) can significantly support these businesses' growth and help them to be competitive in global markets (O. et al., 2015). Many factors affect the adoption of social media, whether these factors are positive, known as drivers, or negative, known as barriers. Moreover, in their adoption of social media, small businesses may face non-technical barriers, which include "soft" factors, such as management's attitude and employees' acceptance (Meske and Stieglitz, 2013). These soft factors need to be considered when small businesses adopt social media. Many studies, on the other hand, have examined the degree to which small businesses may benefit from social media. The determinants of social media benefits for a small business include the business's readiness to adopt not only the technology but also the challenges that come with social media. Stakeholder pressure and competitive pressure are the most significant factors in determining social media benefits (Schaupp and Bélanger, 2016)(Alsobhi and Abeysinghe, 2014).

The platforms that have received the most focus in studies on social media are Facebook and Twitter.

(Wamba and Carter, 2013, Wamba and Carter, 2016) introduced an adoption model that explains the roles of organizations, the managers' characteristics, and environmental factors in Small and Medium Enterprises (SMEs') adoption of Twitter and Facebook. This implies that organizations' innovativeness, their sizes, the managers' ages, their industry sectors, and their geographic locations have a significant impact on SMEs' adoption of social media.

In Saudi Arabia, the number of small businesses is rapidly increasing (2016). This is due to the government's support of private sector growth as a way of decreasing the country's dependence on oil, which is one of the Saudi Vision 2030 goals. Saudi small businesses, according to Saudi SMEs, are any businesses with six to 49 employees and with sales between three to 50 million SR (Pownall, 2016). However, little research to date has emphasized these 
businesses' social media adoption. (AlHusain and Mirza, 2015) studied how Saudi small business entrepreneurs used Twitter as a virtual shop for selling their products. Many entrepreneurs have discovered that using Twitter can be effective when it comes to communicating effectively with customers. The authors concluded that using such a platform can certainly help businesses to attract and acquire customers, but it can still be difficult for customers to make deals with anonymous people. However, again, these findings are with respect to only one social media platform, which is Twitter, and this may not be applicable to other social media platforms, such as Instagram, Facebook, LinkedIn, and Snapchat.

\section{Selection of Appropriate Theory for Proposed Model}

\subsection{Proposed Studies}

Having a systematic model that identifies the factors influencing small businesses' acceptance of social media adoption is important. Limited research studies have covered this subject. (Shokrey et al., 2016) identified the factors affecting accepting social media as a platform among student entrepreneurs in Malaysia. They used the modified UTAUT model as a framework for examining social media acceptance. They discovered that performance expectancy, effort expectancy, social influence, facilitating condition, and perceived enjoyment are the factors that mostly affect social media acceptance. However, this study focused on the perspective of student entrepreneurs, who can benefit from using social media as a start-up strategy, which may not apply for other entrepreneurs. Similarly, the UTAUT was used as a basic framework for studying the factors influencing African-American small businesses (AASBs) that adopt social media in their businesses (Thomas et al., 2014). The result indicated that performance expectancy, social influence, and facilitating conditions positively affected the AASB owner's intention to use social media. Moreover, a theory of factors influencing the strategic application of social media in Swiss SMEs with respect to the technology acceptance model (TAM) was developed. The results implied that the expectation of low returns along with high perceived risks influence SME executives' decision not to adopt social media applications in their companies (Beier and Wagner, 2016).

\subsection{Theoretical Model}

Successful social media adoption relies heavily on addressing the acceptance of the use of social media as a business platform. To better understand the acceptance of such technology, and to predict certain outcomes, an analysis of theoretical models is proposed here. These models include the theory of reasoned action (TRA), technology acceptance model (TAM), and UTAUT.

The TRA, which (Fishbein, 1979) developed, is one of the most popular acceptance theories, focusing primarily on the prediction of individuals' intentions to perform certain behaviors. The theory is based on two aspects: the attitude toward a behavior, and the perception of social influence. Although the TRA is a well-established framework, it mainly explains individuals' behaviors, not necessarily businesses' behaviors. The TAM, on the other hand, is based on the TRA. Developed by (Davis et al., 1989), it is defined as "an adaptation of Theory of Reasoned Action (TRA) specifically tailored for modelling user acceptance of information systems." The TAM introduces primarily two factors - the perceived ease of use and the perceived usefulness - that are important for determining a user's attitude toward use, as well as his or her intention to use, which eventually leads to actual use. Many research studies revealed that the TAM is a solid predictive model. However, some indications exist that the TAM fails to cover other predictive variables that may affect the acceptance behavior. The TAM was later extended to the UTAUT.

The UTAUT model, which (Venkatesh et al., 2003) developed, is the result of a combination of eight information technology acceptance models. In this model, the validity of all eight models is examined to determine the behavioral intention and actual use and adoption. These eight models are the TRA, the TAM, the theory of planned behavior (TPB), the motivational model (MM), the model of PC utilization (MPCU), the innovation diffusion theory (ID), the combined TPB/TAM, and social cognitive theory (SCT). The UTAUT theory identifies four constructs that directly examines the behavioral intention toward accepting and therefore using technology. These constructs are as follows: performance expectancy, effort expectancy, social influence, and facilitating conditions. In addition, the theory adds four moderators that indirectly affect the intention and use of technology: age, gender, experience, and the voluntariness of use. Considering the previous models, the UTAUT model was more appropriate in the context of the current research study. This is because it is a comprehensive model that combines all previous acceptance models. In addition, the UTAUT was proposed to explain technology acceptance from an organizational perspective, which is what was needed in this study. Furthermore, the UTAUT has been used to examine the acceptance of e-government services in the United Arab Emirates (Rodrigues et al., 2016) and Radio Frequency Identification (RFID)-enabled services (Nysveen and Pedersen, 2016) which can be considered similar to social media due to the similarity in the technologies. Finally, the UTAUT model examines the acceptance of information technology with direct and indirect 
moderator factors. These moderators are critical to such studies, especially in the Saudi context, due to the high number of young people who have small startup businesses - both male and female - along with the rising number of social media users in Saudi Arabia. In addition, this study was aimed at inspecting the motives behind Saudi small business entrepreneurs when adopting social media. The moderator "voluntariness of use" was neglected in this study, as it was assumed that entrepreneurs when adopting such a technology have free will and are not forced to adopt it. Therefore, the UTAUT was selected as the theoretical foundation of our study.

The review of the literature reviewed that only a few studies have shed light on the adoption and use of social media among small businesses, not to mention in the Saudi context. As a result, the UTAUT was used as a base framework for examining the intentions of small businesses to accept and therefore adopt social media in their businesses.

\section{Significance of the Study}

Businesses, not to mention small businesses, extensively use technology to streamline their businesses and to facilitate the flow of information between themselves and their customers,

or between customers.

This study is significant, especially in the field of business, as it may help in both research field and business investigating the relationship between social media adoption and Saudi small businesses.

By focusing on small businesses in Saudi Arabia, and by using the UTAUT model with the elimination of one moderator, voluntariness, this study explored an area where no exhaustive studies exist and where exploration is still needed. In addition, this research study adds to studies about the applicability of the UTAUT in the business environment.

\section{Limitations of the UTAUT Model}

UTAUT model has proved to be a robust model and is used widely in information technology given its ability to explain about $69 \%$ of technology acceptance and intention to use. However, it has limitations. One limitation is that the construct of facilitating conditions explains the external factors and uncertainties that come with the intention to use, which may lead to a difference in an individual's belief and in his or her behavioral intention, as behavioral intention cannot predict uncontrolled behaviors (Moghavvemi et al., 2012). In addition, the UTAUT model may lead to a splinter of knowledge, as it has too many independent variables, which can lead to chaos (Bagozzi, 2007).

\section{Conceptual Model}

This study's goal was to identify the antecedents of Saudi small businesses' social media adoption. As a result, this study was based on UTAUT model constructs (performance expectancy, effort expectancy, social influence, and facilitating conditions) and four moderators (age, gender, and experience).

The definition of these constructs is as follows:

Table 1. Major constructs of the conceptual model

\begin{tabular}{|c|c|}
\hline Construct & Definition \\
\hline $\begin{array}{l}\text { Performance Expectancy } \\
\text { (PE) }\end{array}$ & $\begin{array}{l}\text { The degree to which an individual believes that using the system will help him } \\
\text { or her to attain gains in job performance }\end{array}$ \\
\hline Effort Expectancy (EE) & The degree of ease associated with the use of the system \\
\hline Social Influence (SI) & $\begin{array}{l}\text { The degree to which an individual perceives that important others believe he or } \\
\text { she should use the new system }\end{array}$ \\
\hline Facilitating Conditions (FC) & $\begin{array}{l}\text { The degree to which an individual believes that an organizational and } \\
\text { technical infrastructure exists to support use of the system }\end{array}$ \\
\hline
\end{tabular}




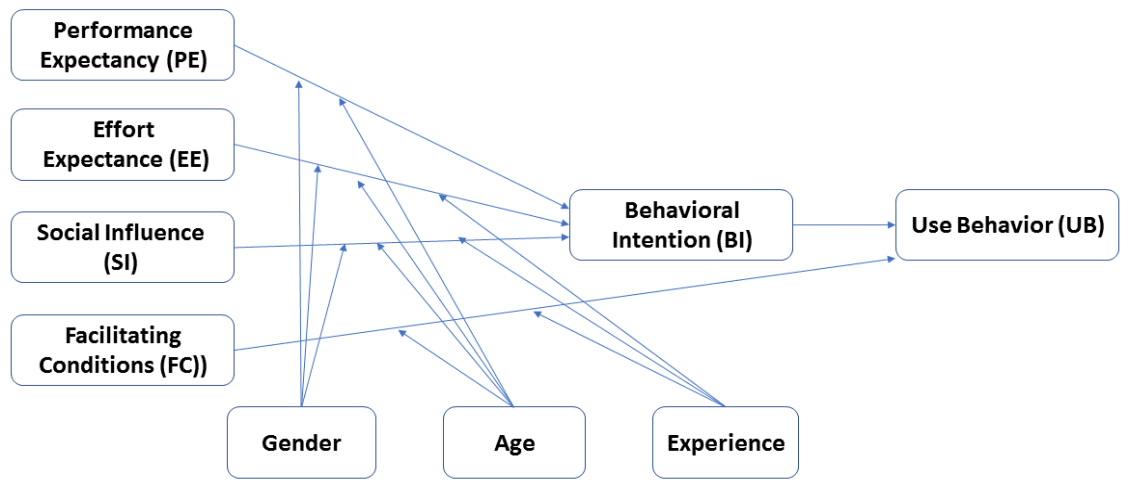

Figure 1. Conceptual model

\section{Hypothesis}

In this paper, the UTAUT is used as a base framework for examining small business entrepreneurs' intentions to accept and therefore adopt social media in their businesses. The UTAUT model examines the basic technology acceptance factors, which are as follows: performance expectancy, effort expectancy, social influence, and facilitating conditions.

\subsection{Performance Expectancy}

Performance expectancy is considered the most influential predictor of intention and can be defined as "the degree to which an individual believes that using the system can help himlher to attain gain in job performance" (Venkatesh et al., 2003). Gender and age moderate this construct, which has a greater effect on men and younger workers (Thomas et al., 2014, Moghavvemi et al., 2011). Accordingly, the following hypothesis was posited in this study:

H1: Performance expectancy will significantly influence small business entrepreneurs' behavioral intention to use social media moderated by age and gender, with it being more salient in men and younger workers.

\section{Effort expectancy}

Effort expectancy is defined as "the degree of ease associated with the use of the system" (Venkatesh et al., 2003). This construct can have more of an effect in the early stages of adopting new information technology and is moderated by gender, age, and experience. It was found that women can affect this construct more than men can, and older workers can affect it more that young ones can (Gruzd et al., 2012). Therefore, the following hypothesis was posited:

H2: Effort expectancy will significantly influence small business entrepreneurs' behavioral intention to use social media moderated by age, gender, and experience, with moderators being more salient in women and older workers.

\subsection{Social Influence}

Social influence is defined as "the degree of users affected by other people's viewpoints and attitudes" (Venkatesh et al., 2003). Age, gender, and experience moderate this construct. As previous research studies highlighted, controversy surrounds the effect of the moderators. (Akbar, 2014) and(Moghavvemi et al., 2012) revealed a salient effect on women and older workers compared with others. (Thomas et al., 2014) found that social influence has a positive influence on the intention to use social media not moderated by age, gender, or experience.

Based on the above conflict, the need exists to emphasize the effect of the moderators of age, gender, and experience, respectively, in the context of Saudi small business. As a result, the following hypothesis was posited:

H3: Social influence will significantly influence small business entrepreneurs' behavioral intention to use social media moderated by age, gender, and experience, with moderators being more salient in women and older workers.

\subsection{Facilitating Conditions}

Facilitating conditions are defined as "the degree to which an individual believes that an organizational and technical infrastructure exists to support the system" (Venkatesh et al., 2003). Age and experience moderate this construct. As 
(Dulle and Minishi-Majanja, 2011) indicated, the construct is stronger in older workers with increased experience.

H4: Facilitating conditions will not have a significant influence on small business entrepreneurs' behavioral intention to use social media.

H5: Facilitating conditions will significantly influence small business entrepreneurs' actual use of social media moderated by age and experience, with moderators being more salient in older workers with increased experience.

\subsection{Intention to Use}

As for behavioral intention, according to (Venkatesh et al., 2003), "behavioral intention will have a significant influence on usage." As a result, the related hypothesis did not need to be tested.

\section{Methodology}

\subsection{Questionnaire Design}

The study used the quantitative method for analyzing the data; the program of SPSS was used for the statistical analysis. The data were gathered using a questionnaire-based survey strategy. Based on the UTAUT model, the questionnaire contained 22 statements covering the six dimensions of the model: performance expectance, effort expectance, social influence, facilitating conditions, behavioral intention, and use behavior. The questionnaire featured two parts: whether small business entrepreneurs use social media, and the type of social media used. In addition, more factual data were sought regarding age, gender, experience, and education level. Then, a Likert scale was used in the rest of the questionnaire. Questionnaire items are displayed in Table 2.

Table 2. Questionnaire items with corresponding constructs

\begin{tabular}{|c|c|c|}
\hline construct & Corresponding items & Item source \\
\hline $\begin{array}{l}\text { Performance } \\
\text { expectance } \\
\text { (PE) }\end{array}$ & $\begin{array}{l}\text { (PE1): Using social media networks enables me to accomplish tasks more } \\
\text { effectively. } \\
\text { (PE2): Using social media networks improves my job performance. } \\
\text { (PE3): Using social media networks helps to improve the quality of customer } \\
\text { service. } \\
\text { (PE4): Overall, I think social media networks are advantageous to my business. }\end{array}$ & $\begin{array}{l}\text { (Venkatesh et al., 2003, } \\
\text { Venkatesh and Zhang, } \\
\text { 2010) }\end{array}$ \\
\hline $\begin{array}{l}\text { Effort } \\
\text { expectancy } \\
\text { (EE) }\end{array}$ & $\begin{array}{l}\text { (EE1): Learning to use social media networks was easy for me. } \\
\text { (EE2): It was easy for me to become skilled in using social media networks. } \\
\text { (EE3): I can say that social media networks are easy to use. } \\
\text { (EE4): Social media networks are easy to handle when a problem occurs. }\end{array}$ & (Venkatesh et al., 2003) \\
\hline $\begin{array}{l}\text { Social } \\
\text { influence (SI) }\end{array}$ & $\begin{array}{l}\text { (SI1): People who are important to me think I should use social media in my } \\
\text { business. } \\
\text { (SI2): People who influence my behavior think I should use social media in my } \\
\text { business. } \\
\text { (SI3): Most people surrounding me use social media in their businesses. } \\
\text { (SI4): In general, the Saudi community is supportive of the use of social media } \\
\text { in business. }\end{array}$ & $\begin{array}{l}\text { (Venkatesh et al., 2003, } \\
\text { Venkatesh and Zhang, } \\
\text { 2010) }\end{array}$ \\
\hline $\begin{array}{l}\text { Facilitating } \\
\text { conditions } \\
\text { (FC) }\end{array}$ & $\begin{array}{l}\text { (FC1): I have the resources necessary to use social media in my business. } \\
\text { (FC2): I have the knowledge necessary to use social media in my business. } \\
\text { (FC3): Social media is compatible with my life. } \\
\text { (FC4): Help is available when I have a problem with using social media in my } \\
\text { business. }\end{array}$ & $\begin{array}{l}\text { (Venkatesh et al., 2003, } \\
\text { Venkatesh and Zhang, } \\
\text { 2010) }\end{array}$ \\
\hline $\begin{array}{l}\text { Behavioral } \\
\text { intention (BI) }\end{array}$ & $\begin{array}{l}\text { (BI1): I think using social media networks in my business is } \\
\text { essential. } \\
\text { (BI2): I think using social media networks in my business is a } \\
\text { positive thing to do. } \\
\text { (BI3): I think using social networks in my business is a good } \\
\text { idea. }\end{array}$ & (Venkatesh et al., 2003) \\
\hline $\begin{array}{l}\text { Use behavior } \\
\text { (UB) }\end{array}$ & $\begin{array}{l}\text { (UB1): I will use/ continue to use social media in my business. } \\
\text { (UB2): In the near future, I plan to begin/ continue to use social } \\
\text { media networks. } \\
\text { (UB3): I plan to extend the use of social media networks in my } \\
\text { business. }\end{array}$ & (Venkatesh et al., 2003) \\
\hline
\end{tabular}




\subsection{Sampling}

The targeted population included small business entrepreneurs in Saudi Arabia. The questionnaire was translated to Arabic for the purpose of gathering accurate information.

\subsection{Pilot Testing}

A pilot test was conducted to improve the questionnaire. A pilot test can improve data quality and minimize potential errors. Ten respondents participated in the pilot. The respondents were interviewed after completing the questionnaire, to spot irregularities and to provide advice for improvement. The pilot test resulted in various changes to the questionnaire that improved the intended meanings of the questions and helped to decrease the likelihood of dropouts.

\section{Data analysis}

\subsection{Validity}

Validity internal consistency of tool:

Validity describes "the degree to which a research study measures what it intends to measure." The Pearson correlation coefficient between each Statement and the total degree of the axis to which they belong is calculated, to know validity of the internal questionnaire, Table 3 reveals that the Pearson correlation coefficient between .741 and .859 , which indicates a strong relationship.

Table 3. Pearson correlation coefficients between each statement and the total degree of measure attitude

\begin{tabular}{cccccc}
\hline Dimension & Question & $\begin{array}{c}\text { Pearson } \\
\text { correlation } \\
\text { coefficient }\end{array}$ & $\begin{array}{c}\text { P-Value } \\
\text { (Sig) }\end{array}$ & $\begin{array}{c}\text { Pearson } \\
\text { correlation } \\
\text { coefficient }\end{array}$ & $\begin{array}{c}\text { P-Value } \\
\text { (Sig) }\end{array}$ \\
\hline Performance & 1 & $0.825^{* *}$ & 0.000 & $0.751^{* *}$ & $\mathbf{0 . 0 0 0}$ \\
expectance & 2 & $0.896^{* *}$ & 0.000 & & \\
& 3 & $0.839^{* *}$ & 0.000 & & \\
Effort expectancy & 4 & $0.858^{* *}$ & 0.000 & & \\
& 5 & $0.776^{* *}$ & 0.000 & $0.777^{* *}$ & $\mathbf{0 . 0 0 0}$ \\
& 6 & $0.792^{* *}$ & 0.000 & & \\
Social influence & 7 & $0.829^{* *}$ & 0.000 & & \\
& 8 & $0.856^{* *}$ & 0.000 & & \\
& 9 & $0.754^{* *}$ & 0.000 & $0.825^{* *}$ & $\mathbf{0 . 0 0 0}$ \\
Facilitating conditions & 10 & $0.831^{* *}$ & 0.000 & & \\
& 11 & $0.750^{* *}$ & 0.000 & & \\
Behavioral intention & 12 & $0.699^{* *}$ & 0.000 & & \\
& 13 & $0.740^{* *}$ & 0.000 & $0.741^{* *}$ & $\mathbf{0 . 0 0 0}$ \\
& 14 & $0.887^{* *}$ & 0.000 & & \\
Use behavior & 15 & $0.833^{* *}$ & 0.000 & & \\
& 16 & $0.837^{* *}$ & 0.000 & $0.776^{* *}$ & $\mathbf{0 . 0 0 0}$ \\
& 17 & $0.924^{* *}$ & 0.000 & & \\
& 18 & $0.910^{* *}$ & 0.000 & & \\
& 19 & $0.876^{* *}$ & 0.000 & $0.859^{* *}$ & $\mathbf{0 . 0 0 0}$ \\
& 20 & $0.870^{* *}$ & 0.000 & & \\
\hline
\end{tabular}

\subsection{Statistical Reliability}

Reliability describes the extent to which the collected data yield consistent findings. A reliable study will return the same results when another researcher replicates it. Validity assures the credibility of a research study. To determine reliability, this study used Cronbach's alpha to measure internal consistency, for example, how closely related a set of items are as a group. Generally, a questionnaire with an $\alpha$ of 0.7 is considered reliable.

That overall reliability coefficient is 0.932 as displayed in Table 4 . This indicates that the tool is stable, which achieves the purpose of the statistical analysis. 
Table 4. Reliability coefficients for Cronbach's alpha

\begin{tabular}{ccc}
\hline Dimension & Items & Coefficients for Cronbach's alpha \\
\hline Performance expectancy & 4 & 0.874 \\
Effort expectancy & 4 & 0.822 \\
Social influence & 4 & 0.746 \\
Facilitating conditions & 3 & 0.750 \\
Behavioral intention & 3 & 0.863 \\
Use behavior & 3 & 0.835 \\
Total & $\mathbf{2 1}$ & $\mathbf{0 . 9 3 2}$ \\
\hline
\end{tabular}

\subsection{Adequacy of the Sample}

An adequate sampling is a statistical sample size that is sufficiently large to provide satisfactory precision test results by minimizing the effect of chance. This study used the Kaiser-Meyer-Olkin (KMO) test to determine if the collected data were suitable for factor analysis. The KMO test measures sampling adequacy for the complete model and for each variable in the model. The test measures the proportion of variance among variables that might be a common variance. A low proportion indicates that the data are suitable for factor analysis. In other words, the lower the proportion, the more suitable the data. KMO values above 0.5 indicate that the sampling is adequate.

Table 5. KMO measure of sampling adequacy

Kaiser-Meyer-Olkin Measure of Sampling
Adequacy

As indicated in Table 5, the KMO value is 0.816 , which means the sample size is enough.

\subsection{Demographics and General Characteristics of the Respondents}

For demographics and general characteristics, descriptive statistics are used here. As Table reveals, the statistics are as follows: $58.9 \%$ of the sample are female, $41.1 \%$ of them are male, $38.4 \%$ of the sample are 40 to 49 years old, $30.1 \%$ of them are 19 to 29 years old, $24.7 \%$ of them are 30 to 39 years old, $4.1 \%$ of them are 50 years old or older, and $2.7 \%$ of them are 18 years old or younger. Regarding education, the table indicates that $71.2 \%$ of the sample have a bachelor's degree, $11 \%$ of them have a master's degree, $6.8 \%$ of them have completed high school or less, and $4.1 \%$ of them have a PhD. In addition, $83.6 \%$ of the sample have more than three years of experience, $13.7 \%$ have 13 months to three years of experience, and $2.7 \%$ have one year of experience or less. Finally, the above table reveals that $95.9 \%$ of the sample use social media in their businesses, and $4.1 \%$ of them did have not used it.

To be more conclusive, and to ensure no bias in the respondents' answers that may affect the study results, more digging of the data was conducted. As Table 7 indicated, frequencies and percentages were created with respect to gender. From the table, we can see that no major differences between the female and male responses that would affect the findings were found. As depicted, most of the male respondents (46\%) are 40 to 49 years old, and most of the female respondents (32\%) are 40 to 49 years old. In addition, $56 \%$ of the male respondents have a bachelor's degree, and $82 \%$ of the female respondents also have a bachelor's degree. Finally, both male and female respondents scored high in the area of having more than three years of experience, with the percentages being $76.7 \%$ and $88.4 \%$ respectively.

As for the type of social media used in business, Table 8 reveals that of the 73 business entrepreneurs, $95.9 \%$ already use social media in their businesses, whereas $4.1 \%$ have not used it. Among those who use social media in their businesses, WhatsApp has the highest usage rate at $14.3 \%$. Second, the rate is $12.9 \%$ for those who use Instagram, Twitter, Snapchat, and WhatsApp or those who use Twitter and WhatsApp. Third, the rate is $8.6 \%$ for those who use Twitter. Fourth, the rate is 5.7\% for those who use Instagram, Snapchat, and WhatsApp; Twitter, Instagram, Facebook, Snapchat, and WhatsApp; or Twitter, Snapchat, and WhatsApp. Fifth, the rate is $4.3 \%$ for the users of Instagram; Instagram and WhatsApp; or Instagram, WhatsApp, and Twitter. Sixth, the rate is $2.9 \%$ for the users of Twitter, Snapchat, Path, and WhatsApp or for those who use Snapchat and WhatsApp. Finally, the rate is $1.4 \%$ for the users of Instagram and Snapchat; Instagram, Facebook, and WhatsApp; Twitter and Instagram; Twitter, Instagram, and Web Page; Twitter, Instagram, Snapchat, WhatsApp, and Telegram; Twitter, Instagram, and Facebook; Twitter, Instagram, Facebook, and Snapchat; or Snapchat. 
Table 6. Frequencies and percentages according to demographic information

\begin{tabular}{cccc}
\hline Variables & Answers & Frequencies & + \\
\hline Gender & Male & 30 & $41.1 \%$ \\
& Female & 43 & $58.9 \%$ \\
Age & Total & 73 & $100.0 \%$ \\
& 18 or less & 2 & $2.7 \%$ \\
& 19 to 29 & 22 & $30.1 \%$ \\
& 30 to 39 & 18 & $24.7 \%$ \\
& 40 to 49 & 28 & $38.4 \%$ \\
Educational level & 50 or more & 3 & $4.1 \%$ \\
& Total & 73 & $100.0 \%$ \\
& High school or less & 5 & $6.8 \%$ \\
& Diploma & 5 & $6.8 \%$ \\
& Bachelor's degree & 52 & $71.2 \%$ \\
& Master's degree & 8 & $11.0 \%$ \\
Years of experience & PhD & 3 & $4.1 \%$ \\
& Total & 73 & $100.0 \%$ \\
& One years or less & 2 & $2.7 \%$ \\
& 13 months to 3 years & 10 & $13.7 \%$ \\
Do you use social & More than three years & 61 & $83.6 \%$ \\
media in your & Total & 73 & $100.0 \%$ \\
establishment? & Yes & 70 & $95.9 \%$ \\
\hline
\end{tabular}

Table 7. Frequencies and percentages according to demographics, gender

\begin{tabular}{|c|c|c|c|c|c|}
\hline & & \multicolumn{2}{|c|}{ Male 30(41.1\%) } & \multicolumn{2}{|c|}{ Female 43(58.9\%) } \\
\hline Variables & Answers & Frequencies & Percentages & Frequencies & Percentages \\
\hline \multirow[t]{6}{*}{ Age } & 18 or less & 0 & $0 \%$ & 2 & $4.7 \%$ \\
\hline & 19 to 29 & 7 & $23.3 \%$ & 15 & $34.9 \%$ \\
\hline & 30 to 39 & 7 & $23.3 \%$ & 11 & $25.6 \%$ \\
\hline & 40 to 49 & 14 & $46.7 \%$ & 14 & $32.6 \%$ \\
\hline & 50 or more & 2 & $6.7 \%$ & 1 & $2.3 \%$ \\
\hline & Total & 30 & $100.0 \%$ & 43 & $100.0 \%$ \\
\hline \multirow[t]{6}{*}{ Educational level } & $\begin{array}{c}\text { High school or } \\
\text { less }\end{array}$ & 3 & $10.0 \%$ & 2 & $4.7 \%$ \\
\hline & Diploma & 4 & $13.3 \%$ & 1 & $2.3 \%$ \\
\hline & $\begin{array}{l}\text { Bachelor's } \\
\text { degree }\end{array}$ & 17 & $56.7 \%$ & 35 & $81.4 \%$ \\
\hline & Master's degree & 5 & $16.7 \%$ & 3 & $7.0 \%$ \\
\hline & $\mathrm{PhD}$ & 1 & $3.3 \%$ & 2 & $4.7 \%$ \\
\hline & Total & 30 & $100.0 \%$ & 43 & $100.0 \%$ \\
\hline \multirow[t]{4}{*}{$\begin{array}{c}\text { Years of } \\
\text { experience }\end{array}$} & $\begin{array}{c}\text { One years or } \\
\text { less }\end{array}$ & 1 & $3.3 \%$ & 1 & $2.3 \%$ \\
\hline & $\begin{array}{c}13 \text { months to } 3 \\
\text { years }\end{array}$ & 6 & $20.0 \%$ & 4 & $9.3 \%$ \\
\hline & $\begin{array}{c}\text { More than three } \\
\text { years }\end{array}$ & 23 & $76.7 \%$ & 38 & $88.4 \%$ \\
\hline & Total & 30 & $100.0 \%$ & 43 & $100.0 \%$ \\
\hline \multirow{3}{*}{$\begin{array}{l}\text { Do you use social } \\
\text { media in your } \\
\text { establishment? }\end{array}$} & Yes & 28 & $93.3 \%$ & 42 & $97.7 \%$ \\
\hline & No & 2 & $6.7 \%$ & 1 & $2.3 \%$ \\
\hline & Total & 30 & $100.0 \%$ & 43 & $100.0 \%$ \\
\hline
\end{tabular}


Table 8. Frequencies and percentages according to the type of social media used in business

\begin{tabular}{ccc}
\hline Answers & Frequencies & Percentages \\
\hline WhatsApp & 10 & $14.3 \%$ \\
Twitter, Instagram, Snapchat, WhatsApp & 9 & $12.9 \%$ \\
Twitter, WhatsApp & 9 & $12.9 \%$ \\
Twitter & 6 & $8.6 \%$ \\
Instagram, Snapchat, WhatsApp & 4 & $5.7 \%$ \\
Twitter, Instagram, Facebook, Snapchat, WhatsApp & 4 & $5.7 \%$ \\
Twitter, Snapchat, WhatsApp & 4 & $5.7 \%$ \\
Instagram & 3 & $4.3 \%$ \\
Instagram, WhatsApp & 3 & $4.3 \%$ \\
Twitter, Instagram, WhatsApp & 3 & $4.3 \%$ \\
Twitter, Snapchat, Path, WhatsApp & 3 & $4.3 \%$ \\
Twitter, Instagram, Snapchat, Path, WhatsApp & 2 & $2.9 \%$ \\
Snapchat, WhatsApp & 2 & $2.9 \%$ \\
Instagram, Snapchat & 1 & $1.4 \%$ \\
Instagram, Facebook, WhatsApp & 1 & $1.4 \%$ \\
Twitter, Instagram & 1 & $1.4 \%$ \\
Twitter, Instagram, Web page & 1 & $1.4 \%$ \\
Twitter, Instagram, Facebook & 1 & $1.4 \%$ \\
Twitter, Instagram, Facebook, Snapchat & 1 & $1.4 \%$ \\
Snapchat & 1 & $1.4 \%$ \\
Total & 1 & $1.4 \%$ \\
Twitter, Instagram, Snapchat, WhatsApp, Telegram & $\mathbf{7 0}$ & $\mathbf{1 0 0 . 0 \%}$ \\
\hline
\end{tabular}

\subsection{Descriptive Statistics}

An important aspect of this paper is to focus on the items and their indications. When using the Likert scale from 1 to 5 , it is crucial to identify the frequencies, percentages, standard deviation, and mean as well as to interpret these numbers to fully understand the study. As Table indicates, we found that most of the items recorded the highest percentages on the scale for "strongly agree," and appropriate numbers of both mean and standard deviations were found (1-1.79 low, 2.60-3.90 moderate, and 4.20-5 high). This can be interpreted as the idea that all Saudi entrepreneurs of small businesses have a positive opinion about the constructs of our study: effort expectancy, performance expectancy, social influence, facilitating conditions, behavioral intention, and behavioral use.

Table 9. Frequencies, percentage, mean, and standard deviation for each statement

\begin{tabular}{l} 
Statement \\
\hline No
\end{tabular}




\begin{tabular}{|c|c|c|c|c|c|c|c|c|c|c|}
\hline 3 & $\begin{array}{l}\text { (EE3): I can say that social media } \\
\text { networks are easy to use. }\end{array}$ & $\begin{array}{c}29 \\
39.7 \%\end{array}$ & $\begin{array}{c}40 \\
54.8 \%\end{array}$ & $\begin{array}{c}4 \\
5.5 \%\end{array}$ & - & - & 4.34 & 0.58 & 1 & $\begin{array}{c}\text { Strongly } \\
\text { agree }\end{array}$ \\
\hline 2 & $\begin{array}{l}\text { (EE2): It was easy for me to } \\
\text { become skilled in using social } \\
\text { media networks. }\end{array}$ & $\begin{array}{c}27 \\
37 \%\end{array}$ & $\begin{array}{c}41 \\
56.2 \%\end{array}$ & $\begin{array}{c}5 \\
6.8 \%\end{array}$ & - & - & 4.30 & 0.59 & 2 & $\begin{array}{c}\text { Strongly } \\
\text { agree }\end{array}$ \\
\hline 1 & $\begin{array}{l}\text { (EE1): Learning to use social } \\
\text { media networks was easy for me. }\end{array}$ & $\begin{array}{c}29 \\
39.7 \%\end{array}$ & $\begin{array}{c}35 \\
47.9 \%\end{array}$ & $\begin{array}{c}9 \\
12.3 \%\end{array}$ & - & - & 4.27 & 0.67 & 3 & $\begin{array}{c}\text { Strongly } \\
\text { agree }\end{array}$ \\
\hline 4 & $\begin{array}{l}\text { (EE4): Social media networks are } \\
\text { easy to handle when a problem } \\
\text { occurs. }\end{array}$ & $\begin{array}{c}26 \\
35.6 \%\end{array}$ & $\begin{array}{c}30 \\
41.1 \%\end{array}$ & $\begin{array}{c}15 \\
20.5 \%\end{array}$ & $\begin{array}{c}2 \\
2.7 \%\end{array}$ & - & 4.10 & 0.82 & 4 & Agree \\
\hline 3 & $\begin{array}{l}\text { (SI3): Most people surrounding me } \\
\text { use social media in their } \\
\text { businesses. }\end{array}$ & $\begin{array}{c}54 \\
74 \%\end{array}$ & $\begin{array}{c}16 \\
21.9 \%\end{array}$ & $\begin{array}{c}2 \\
2.7 \%\end{array}$ & $\begin{array}{c}1 \\
1.4 \%\end{array}$ & - & 4.67 & 0.67 & 1 & $\begin{array}{c}\text { Strongly } \\
\text { agree }\end{array}$ \\
\hline 4 & $\begin{array}{l}\text { (SI4): In general, the Saudi } \\
\text { community is supportive of the use } \\
\text { of social media in business. }\end{array}$ & $\begin{array}{c}48 \\
65.8 \%\end{array}$ & $\begin{array}{c}20 \\
27.4 \%\end{array}$ & $\begin{array}{c}3 \\
4.1 \%\end{array}$ & $\begin{array}{c}2 \\
2.7 \%\end{array}$ & - & 4.56 & 0.71 & 2 & $\begin{array}{c}\text { Strongly } \\
\text { agree }\end{array}$ \\
\hline 2 & $\begin{array}{l}\text { (SI2): People who influence my } \\
\text { behavior (customers, competitors, } \\
\text { etc.) think I should use social } \\
\text { media in my business. }\end{array}$ & $\begin{array}{c}41 \\
56.2 \%\end{array}$ & $\begin{array}{c}27 \\
37 \%\end{array}$ & $\begin{array}{c}5 \\
6.8 \%\end{array}$ & - & - & 4.49 & 0.63 & 3 & $\begin{array}{c}\text { Strongly } \\
\text { agree }\end{array}$ \\
\hline 1 & $\begin{array}{l}\text { (SI1): People who are important to } \\
\text { me (friends, family, etc.) think I } \\
\text { should use social media in my } \\
\text { business. }\end{array}$ & $\begin{array}{c}33 \\
45.2 \%\end{array}$ & $\begin{array}{c}29 \\
39.7 \%\end{array}$ & $\begin{array}{c}9 \\
12.3 \%\end{array}$ & $\begin{array}{c}2 \\
2.7 \%\end{array}$ & - & 4.27 & 0.79 & 4 & $\begin{array}{c}\text { Strongly } \\
\text { agree }\end{array}$ \\
\hline 1 & $\begin{array}{l}\text { (FC1): I have the resources } \\
\text { (smartphone, internet, etc.) } \\
\text { necessary to use social media in } \\
\text { my business. }\end{array}$ & $\begin{array}{c}45 \\
61.6 \%\end{array}$ & $\begin{array}{c}22 \\
30.1 \%\end{array}$ & $\begin{array}{c}6 \\
8.2 \%\end{array}$ & - & - & 4.53 & 0.65 & 1 & $\begin{array}{c}\text { Strongly } \\
\text { agree }\end{array}$ \\
\hline 2 & $\begin{array}{l}\text { (FC2): I have the knowledge } \\
\text { necessary to use social media in } \\
\text { my business. }\end{array}$ & $\begin{array}{c}36 \\
49.3 \%\end{array}$ & $\begin{array}{c}31 \\
42.5 \%\end{array}$ & $\begin{array}{c}5 \\
6.8 \%\end{array}$ & $\begin{array}{c}1 \\
1.4 \%\end{array}$ & - & 4.40 & 0.68 & 2 & $\begin{array}{c}\text { Strongly } \\
\text { agree }\end{array}$ \\
\hline 3 & $\begin{array}{l}\text { (FC3): Technical support is } \\
\text { available when I have a problem } \\
\text { with using social media in my } \\
\text { business. }\end{array}$ & $\begin{array}{c}27 \\
37 \%\end{array}$ & $\begin{array}{c}29 \\
39.7 \%\end{array}$ & $\begin{array}{c}14 \\
19.2 \%\end{array}$ & $\begin{array}{c}3 \\
4.1 \%\end{array}$ & - & 4.10 & 0.85 & 3 & Agree \\
\hline 3 & $\begin{array}{l}\text { (BI3): I think using social networks } \\
\text { in my business is a good idea. }\end{array}$ & $\begin{array}{c}42 \\
57.5 \%\end{array}$ & $\begin{array}{c}27 \\
37 \%\end{array}$ & $\begin{array}{c}4 \\
5.5 \%\end{array}$ & - & - & 4.52 & 0.60 & 1 & $\begin{array}{c}\text { Strongly } \\
\text { agree }\end{array}$ \\
\hline 2 & $\begin{array}{l}\text { (BI2): I think using social media } \\
\text { networks in my business is a } \\
\text { positive thing to do. }\end{array}$ & $\begin{array}{c}41 \\
56.2 \%\end{array}$ & $\begin{array}{c}25 \\
34.2 \%\end{array}$ & $\begin{array}{c}6 \\
8.2 \%\end{array}$ & $\begin{array}{c}1 \\
1.4 \%\end{array}$ & - & 4.45 & 0.71 & 2 & $\begin{array}{c}\text { Strongly } \\
\text { agree }\end{array}$ \\
\hline 1 & $\begin{array}{l}\text { (BI1): I think using social media } \\
\text { networks in my business is } \\
\text { essential. }\end{array}$ & $\begin{array}{c}36 \\
49.3 \%\end{array}$ & $\begin{array}{c}30 \\
41.1 \%\end{array}$ & $\begin{array}{c}5 \\
6.8 \%\end{array}$ & $\begin{array}{c}2 \\
2.7 \%\end{array}$ & - & 4.37 & 0.74 & 3 & $\begin{array}{c}\text { Strongly } \\
\text { agree }\end{array}$ \\
\hline 1 & $\begin{array}{l}\text { (UB1): I will use/ continue to use } \\
\text { social media in my business. }\end{array}$ & $\begin{array}{c}42 \\
57.5 \%\end{array}$ & $\begin{array}{c}27 \\
37 \%\end{array}$ & $\begin{array}{c}4 \\
5.5 \%\end{array}$ & - & - & 4.52 & 0.60 & 1 & $\begin{array}{c}\text { Strongly } \\
\text { agree }\end{array}$ \\
\hline 3 & $\begin{array}{l}\text { (UB3): } 1 \text { plan to extend the use of } \\
\text { social media networks in my } \\
\text { business. }\end{array}$ & $\begin{array}{c}43 \\
58.9 \%\end{array}$ & $\begin{array}{c}22 \\
30.1 \%\end{array}$ & $\begin{array}{c}8 \\
11 \%\end{array}$ & - & - & 4.48 & 0.69 & 2 & $\begin{array}{c}\text { Strongly } \\
\text { agree }\end{array}$ \\
\hline 2 & $\begin{array}{l}\text { (UB2): In the near future, I plan } \\
\text { to begin/ continue to use social } \\
\text { media networks. }\end{array}$ & $\begin{array}{c}38 \\
52.1 \%\end{array}$ & $\begin{array}{c}24 \\
32.9 \%\end{array}$ & $\begin{array}{c}10 \\
13.7 \%\end{array}$ & $\begin{array}{c}1 \\
1.4 \%\end{array}$ & - & 4.36 & 0.77 & 3 & $\begin{array}{c}\text { Strongly } \\
\text { agree }\end{array}$ \\
\hline
\end{tabular}

\subsection{Hypothesis Testing}

The main question was as follows: "What influences Saudi small businesses' social media adoption?" 
The null hypotheses accepted or rejected after the analysis are as follows:

N1: Performance expectancy does not have an influence on small business entrepreneurs' behavioral intention to use social media moderated by age and gender, with moderators being more salient in men and younger worker.

N2: Effort expectancy does not have an influence on small business entrepreneurs' behavioral intention to use social media moderated by age, gender, and experience, with moderators being more salient in women and older workers.

N3: Social influence does not have an influence on small business entrepreneurs' behavioral intention to use social media moderated by age, gender, and experience, with moderators being more salient in women and older workers.

N4: Facilitating conditions does not have an influence on small business entrepreneurs' behavioral intention to use social media.

N5: Facilitating conditions does not have an influence on small business entrepreneur's actual use of social media moderated by age and experience in which it is more salient in older workers with increased experience.

\subsubsection{Analysis Using Correlation}

The data were analyzed using the correlation matrix, which is important, as it describes the bivariate associations among the variables. From Table 10, we can see that a statistically significant relationship exists at the level of significance (P-value $=0.05$ ) or less between behavioral intention and performance expectancy/ effort expectancy/ social influence. In addition, a statistically significant relationship exists at the level of significance $(\mathrm{P}$-value $=0.05)$ or less between use behavior and behavioral intention/ facilitating conditions. Moreover, the highest correlation is the one associated with performance expectancy with a value of 0.55 , followed by the value associated with social influence (0.52), facilitating conditions (0.46), and, finally, effort expectancy (0.41).

Table 10. Correlation matrix using Pearson correlation

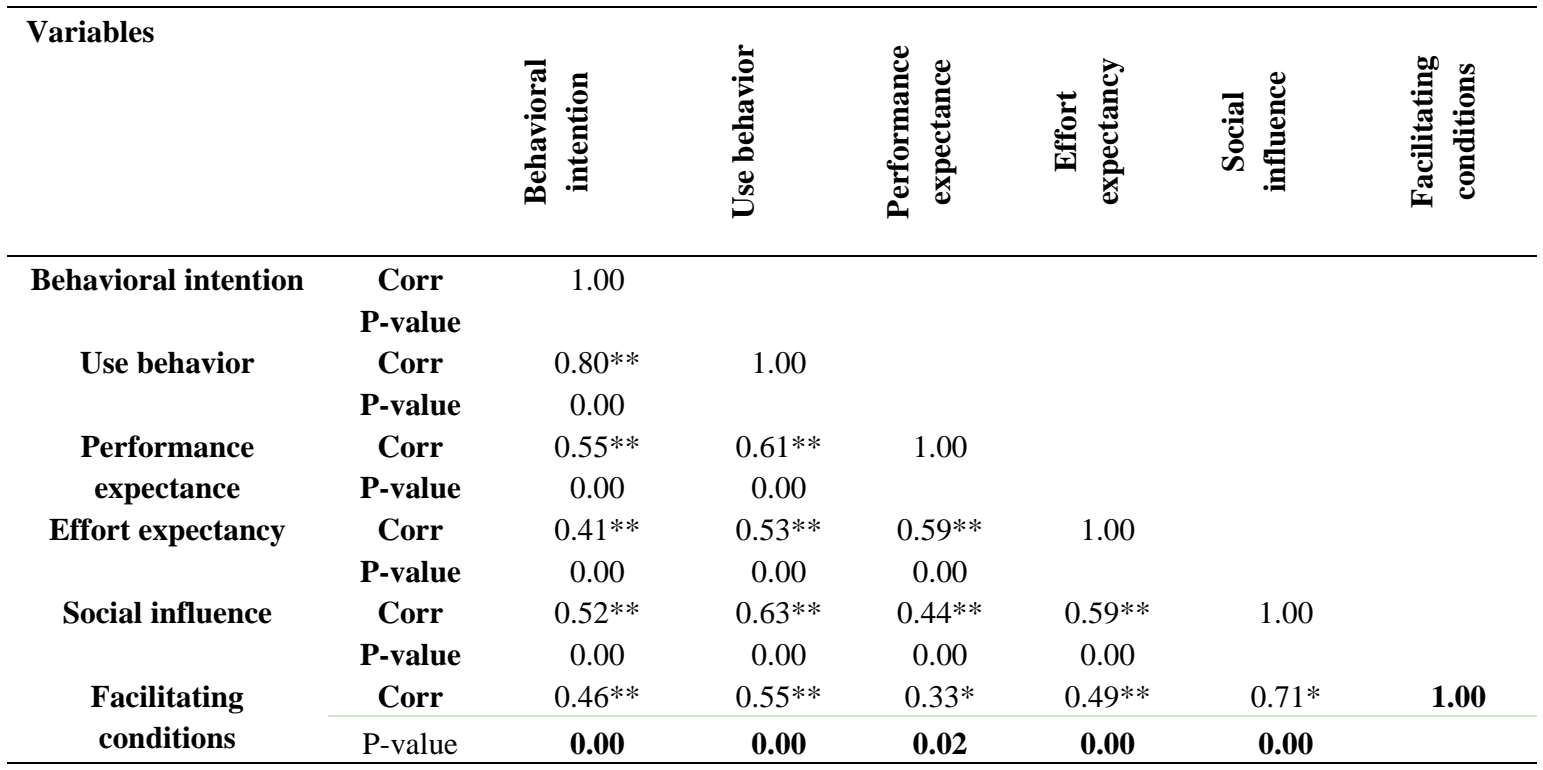

\subsubsection{Analysis Using Multiple Regression}

For further confirmation, the study used multiple regression analysis. This type of analysis was appropriate, as it estimates the relationship between the dependent variable and two or more independent variables, or predictors. As depicted in Table, we can see that a statistically significant influence of the independent variables of performance expectancy, effort expectancy, and social influence on the dependent variable of behavioral intention exists at the level of significance $(\mathrm{P}$-value $=0.05$ ). Also, from Table, we can see that a statistically significant influence of the independent variable of facilitating conditions on the dependent variable of use behavior exists at the level of significance $(\mathrm{P}$-value $=0.05)$. 
Table 11. Analysis using multiple regression 1

\begin{tabular}{|c|c|c|c|c|c|c|}
\hline Dependent variable & \multicolumn{6}{|c|}{ Behavioral intention } \\
\hline & \multicolumn{2}{|c|}{$\begin{array}{l}\text { Unstandardized } \\
\text { coefficients }\end{array}$} & $\begin{array}{c}\text { Standardized } \\
\text { coefficients }\end{array}$ & $\mathrm{T}$ & Sig. & Note \\
\hline Independent variable & $\mathrm{B}$ & $\begin{array}{l}\text { Std. } \\
\text { Error }\end{array}$ & Beta & & & \\
\hline (Constant) & 1.413 & \multicolumn{2}{|l|}{.587} & $2.406^{*}$ & .019 & - \\
\hline Performance expectancy & .345 & .129 & .331 & $\begin{array}{c}2.673^{*} \\
*\end{array}$ & .009 & Positive influence \\
\hline Effort expectancy & .133 & .068 & .131 & $2.218^{*}$ & .028 & Positive influence \\
\hline \multirow[t]{6}{*}{ Social influence } & .297 & .136 & .281 & $2.187 *$ & .032 & Positive influence \\
\hline & \multicolumn{3}{|c|}{$\mathrm{R}$} & 0.539 & & \\
\hline & \multicolumn{3}{|c|}{ R Square } & 0.290 & & \\
\hline & \multicolumn{3}{|c|}{ Adjusted R Square } & 0.259 & & \\
\hline & \multirow{2}{*}{\multicolumn{3}{|c|}{ F-Value }} & 9.401 & & \\
\hline & & & & 0.000 & & \\
\hline
\end{tabular}

Table 12. Analysis using multiple regression 2

\begin{tabular}{|c|c|c|c|c|c|c|}
\hline \multirow{2}{*}{ Dependent variable } & \multicolumn{6}{|c|}{ Use behavior } \\
\hline & \multicolumn{2}{|c|}{$\begin{array}{l}\text { Unstandardized } \\
\text { coefficients }\end{array}$} & $\begin{array}{l}\text { Standardized } \\
\text { coefficients }\end{array}$ & $\mathrm{T}$ & Sig. & Note \\
\hline \multirow{2}{*}{$\begin{array}{l}\text { Independent variable } \\
\text { (Constant) }\end{array}$} & $\mathrm{B}$ & Std. Error & Beta & & & \\
\hline & .487 & .460 & & 1.059 & .293 & - \\
\hline \multirow{7}{*}{$\begin{array}{l}\text { Fehavioral intentions } \\
\text { Behating condions }\end{array}$} & .224 & .089 & .220 & $2.510^{*}$ & .014 & Positive influence \\
\hline & .664 & .094 & .621 & $7.085^{* *}$ & .000 & Positive influence \\
\hline & \multicolumn{3}{|c|}{$\mathrm{R}$} & 0.731 & & \\
\hline & \multicolumn{3}{|c|}{ R Square } & 0.534 & & \\
\hline & \multicolumn{3}{|c|}{ Adjusted R Square } & 0.520 & & \\
\hline & \multirow{2}{*}{\multicolumn{3}{|c|}{ F-Value }} & 40.058 & & \\
\hline & & & P-Value & 0.000 & & \\
\hline
\end{tabular}

It is important, however, to address the influence of the moderators on each one of the study constructs. With the use of multinomial logistic regression analysis for each moderator, from Table13, we can see a statistically significant influence of the male response on effort expectancy at the level of significance (sig=0.05). This means that the female response has a negative influence on effort expectancy. In addition, from Table and Table, we can see that no significant difference exists at the level of significance (sig=0.05) or less between the responses of the sample of the study in all dimensions according to age and experience.

Table 13. Results of multinomial logistic regression for gender

\begin{tabular}{ccccccc}
\hline \multicolumn{7}{c}{ Parameter estimates } \\
\hline Gender ${ }^{\mathrm{a}}$ & Dimension & $\mathrm{B}$ & Std. & Wald & df & Sig. \\
& & & Error \\
Male & Intercept & -0.25 & 2.44 & 0.01 & 1 & 0.92 \\
& Performance expectancy & -0.77 & 0.63 & 1.48 & 1 & 0.22 \\
$\quad$ Effort expectancy & 2.18 & 0.77 & $8.01^{* *}$ & 1 & 0.01 \\
$\quad$ Social influence & -1.13 & 0.65 & 2.97 & 1 & 0.09 \\
& Behavioral intention & -0.24 & 0.57 & 0.19 & 1 & 0.67 \\
& a. The reference category is: female. & & & \\
\end{tabular}


Table 14. Results of multinomial logistics regression for age

\begin{tabular}{|c|c|c|c|c|c|c|}
\hline \multicolumn{7}{|c|}{ Parameter estimates } \\
\hline $\mathrm{Age}^{\mathrm{a}}$ & Dimension & $\mathrm{B}$ & $\begin{array}{l}\text { Std. } \\
\text { Error }\end{array}$ & Wald & df & Sig. \\
\hline \multirow[t]{5}{*}{18 or less } & Intercept & 325.39 & 5235.40 & 0.00 & 1 & 0.95 \\
\hline & $\begin{array}{l}\text { Performance } \\
\text { expectancy }\end{array}$ & -52.44 & 604.33 & 0.01 & 1 & 0.93 \\
\hline & Effort expectancy & -1.35 & 347.54 & 0.00 & 1 & 1.00 \\
\hline & Social influence & 43.03 & 790.48 & 0.00 & 1 & 0.96 \\
\hline & Facilitating conditions & -4.63 & 586.85 & 0.00 & 1 & 0.99 \\
\hline \multirow[t]{5}{*}{19 to 29} & Intercept & 375.78 & 2324.62 & 0.03 & 1 & 0.87 \\
\hline & $\begin{array}{c}\text { Performance } \\
\text { expectancy }\end{array}$ & -41.04 & 473.65 & 0.01 & 1 & 0.93 \\
\hline & Effort expectancy & 9.78 & 107.54 & 0.01 & 1 & 0.93 \\
\hline & Social influence & 20.29 & 76.41 & 0.07 & 1 & 0.79 \\
\hline & Facilitating conditions & 19.10 & 76.41 & 0.06 & 1 & 0.80 \\
\hline \multirow[t]{5}{*}{30 to 39} & Intercept & 372.72 & 2324.62 & 0.03 & 1 & 0.87 \\
\hline & $\begin{array}{l}\text { Performance } \\
\text { expectancy }\end{array}$ & -39.82 & 473.65 & 0.01 & 1 & 0.93 \\
\hline & Effort expectancy & 8.58 & 107.54 & 0.01 & 1 & 0.94 \\
\hline & Social influence & 20.01 & 76.41 & 0.07 & 1 & 0.79 \\
\hline & Facilitating conditions & 19.52 & 76.41 & 0.07 & 1 & 0.80 \\
\hline \multirow[t]{5}{*}{40 to 49} & Intercept & 377.58 & 2324.62 & 0.03 & 1 & 0.87 \\
\hline & $\begin{array}{c}\text { Performance } \\
\text { expectancy }\end{array}$ & -40.41 & 473.65 & 0.01 & 1 & 0.93 \\
\hline & Effort expectancy & 9.74 & 107.54 & 0.01 & 1 & 0.93 \\
\hline & Social influence & 19.52 & 76.41 & 0.07 & 1 & 0.80 \\
\hline & Facilitating conditions & 18.00 & 76.41 & 0.06 & 1 & 0.81 \\
\hline
\end{tabular}

Table 15. Results of multinomial logistic regression for expereince

\begin{tabular}{ccccccc}
\hline \multicolumn{7}{c}{ Parameter estimates } \\
\hline Experience & \multicolumn{7}{c}{ e } & Dimension & $\mathrm{B}$ & Std. Error & Wald & df & Sig. \\
One year or & Intercept & -576.98 & 4880.59 & 0.01 & 1.00 & 0.91 \\
less & Effort expectancy & 82.15 & 1563.28 & 0.00 & 1.00 & 0.96 \\
& Social influence & -71.54 & 1243.94 & 0.00 & 1.00 & 0.95 \\
& Facilitating conditions & 10.92 & 469.95 & 0.00 & 1.00 & 0.98 \\
& Behavioral Intention & 82.79 & 1567.8 & 0.00 & 1.00 & 0.92 \\
13 months to 3 & Use behavior & 10.55 & 747.59 & 0.00 & 1.00 & 0.99 \\
years & Intercept & -1.27 & 3.64 & 0.12 & 1.00 & 0.73 \\
& Effort expectancy & 1.63 & 1.02 & 2.55 & 1.00 & 0.11 \\
& Social influence & -0.77 & 1.02 & 0.56 & 1.00 & 0.45 \\
& Facilitating conditions & -0.79 & 0.83 & 0.92 & 1.00 & 0.34 \\
& Behavioral intention & -0.92 & 0.87 & 1.12 & 1.00 & 0.29 \\
& Use behavior & 0.72 & 0.97 & 0.56 & 1.00 & 0.46 \\
& a. The reference category is: more than 3 years. & & \\
\hline
\end{tabular}

\subsection{Result Discussion}

The purpose of this study was to explore the factors influencing Saudi small business entrepreneurs' adoption of social media using the UTAUT model. As a result, an important step was to answer the main research question: What influences Saudi small businesses' social media adoption? Referring to the results from the previous sections, we can answer the main question and summerize the findings as follows. With respect to the construct of performance 
expectancy, the study revealed that the construct has a significantly positive influence on behavioral intention, which is consistent with previous research (Venkatesh et al., 2003)(Thomas et al., 2014) (Shokrey et al., 2016) . This, as a result, supports hypothesis $\mathrm{H} 1$ and negates null hypothesis N1. In addition, the hypothesis assumed that gender and age would moderate the influence of performance expectancy on behavioral intention. However, the result revealed that both age and gender did not moderate the influence of performance expectancy on behavioral intention, which (Serben, 2014) supported. This implies that Saudi small business entrepreneurs acknowledge the benefits and usefulness of social media regrdless of their gender or age.

With regard to the construct of effort expectancy, the study's findings revealed that a significantly positive influence on behavioral intention exists, which is also consistent with previous research (Venkatesh et al., 2003) (Shokrey et al., 2016) and supports hypothesis H2. The findings also indicated no influence of the moderators of age or expereince, which (Thomas et al., 2014) supported. This can be translated as follows: For Saudi small business entrepreneurs who view social media as highly easy to use, they have a high behavioral intention to use it without any considerations of age or expereince. Surprisingly, the findings revealed that the influence of effort expectancy on behavioral intention is more salient for the male, which intrestingly contrasts with the literature. Previous studies indicated that men are more likely to learn and adopt new technology, whereas women tend to learn the technology from others, with the construct of effort expectancy being more salient for them (Zhou, 2011). However, Saudi Arabia is characterized by cultural traditions that are totally different from those of the West. Although the moderators of age and gender have proved to be significant influencers in the west, these moderators were found to be non-significant in Saudi Arabia (Baker et al., 2007)(Al-Gahtani et al., 2007). Moreover, Saudi women are charecterized by their tendancy to work hard toward their goals, which may explain the findings. As a result, these findings may be due to the cultural differences between the male and female and need to be further studied.

As for the construct of social influence, the study revealed that the construct has a significantly positive influence on behavioral intention, which is consistent with previous research (Venkatesh et al., 2003)(Shokrey et al., 2016) (Thomas et al., 2014), supports hypothesis H3, and negates null hypothesis N3. Furthermore, the hypothesis claimed that gender, age, and experience would moderate the influence of social influence on behavioral intention. As a result, the findings indicated that age, gender, and experience did not moderate the influence of performance expectancy on behavioral intention. Contrary to (Moghavvemi et al., 2012), and in support of (Serben, 2014), they imply that Saudi small business entrepreuers are motivated by the individuals who surround them.

Finally, the findings indicated that the construct of facilitating conditions has a significantly positive influence on the constructs of behavioral intention and use behavior, which is partially consistent with the previous research of (Venkatesh et al., 2003), (Thomas et al., 2014), (Shokrey et al., 2016), and (Foon and Fah, 2011). This rejects hypothesis $\mathrm{H} 4$, supports null hypothesis $\mathrm{N} 4$, supports hypothesis $\mathrm{H} 5$, and negates null hypothesis N5. In addition, the hypothesis claimed that age and experience would moderate the influence of social influence on use behavior. As a result, the findings indicated that both age and experience did not moderate the influence of facilitating conditions on use behavior.

In summary, the results of this study have mixed support for the UTAUT model, where most of the hypotheses, H1, $\mathrm{H} 2, \mathrm{H} 3, \mathrm{H} 4$, and H5, were either supported or partially supported. In other words, in Saudi Arabia, small business entreprenuers adopt social media in their businesses for its ease of use, its benefits, the power of the surrounding people who positively influence their behavior, and the facilitating conditions, which is consistent with (Venkatesh et al., 2003) and thus rejects the null hypothesis and supports hypotheses H1, H2, H3, and H5.

\section{Conclusion}

This preliminary study provided an overview of the influences behind small business entrepreneurs' social media adoption in Saudi Arabia. For the purpose of adding theoretical knowledge, this study applied the UTAUT model as a basic framework. By testing the factors of performance expectancy, effort expectancy, social influence, and facilitating conditions moderated by age, gender, and expereince, the study concluded that small business entrepreneurs use social media in their businesses for its ease of use, its usefulness, its social influence, and the facilitating conditions.

The study findings will add to the literature the factors that mostly influence Saudi small business entrepreneurs' adoption of social media, which will formulate a road map for those who will adopt social media in their businesses in the future.

\section{Recommendations and Further Work}

Regarding recommendations, the need exists for certain kinds of guidelines for using social media for small business 
entrepreneurs in the Saudi context. These guidelines will help entrepreneurs in making the proper use of social media in their businesses.

This study was a preliminary study and focused on a limited sample size. Therefore, a larger study should be carried out that will be more conclusive. Nevertheless, the current study has provided us with insights on what mainly influences social media among small business entrepreneurs. A qualitative future research study on the reasons behind the gender differences for the construct of effort expectancy is needed. In addition, identifying the cultural factors affecting social media adoption along with those studied in this research study is important.

\section{References}

2013. Why mobile commerce is set to explode.

2016. Retrieved from Saudi_Vision2030_EN.pdf

Akbar, F. (2014). Retrieved from What affects students' acceptance and use of technlogy.pdf

AL-Gahtani, S.S., Hubona, G.S., \& Wang, J. (2007). Information technology (IT) in Saudi Arabia: Culture and the acceptance and use of IT. Information \& Management, 44, 681-691. https://doi.org/10.1016/j.im.2007.09.002

Alhusain, D., \& Mirza, A. (2015). twitter and th opportunity for small business entrepreneurs in Sausi arabia. International of Arab Journal for E-Technology, 4.

Alsobhi, A.Y., \& Abeysinghe, G. (2014). Evaluating Social Media Frameworks for Small and Large Organisation.

Bagozzi, R.P. (2007). The legacy of the technology acceptance model and a proposal for a paradigm shift. Journal of the Association for Information Systems, 8, 3. https://doi.org/10.17705/1jais.00122

Baker, E.W., Al-Gahtani, S.S., \& Hubona, G.S. (2007). The effects of gender and age on new technology implementation in a developing country: Testing the theory of planned behavior (TPB). Information Technology \& People, 20, 352-375. https://doi.org/10.1108/09593840710839798

Beier, M., \& Wagner, K. (2016). Social Media Adoption Barriers to the Strategic Use of Social Media in Smes. Association for Information Systems AIS Electronic Library (AISeL).

Davis, F.D., Bagozzi, R.P., \& Warshaw, P.R. (1989). User acceptance of computer technology: a comparison of two theoretical models. Management science, 35, 982-1003. https://doi.org/10.1287/mnsc.35.8.982

Dulle, F.W., \& Minishi-Majanja, M.K. (2011). The suitability of the Unified Theory of Acceptance and Use of Technology (UTAUT) model in open access adoption studies. Information Development, 27, 32-45. https://doi.org/10.1177/0266666910385375

Fishbein, M. (1979). A theory of reasoned action: some applications and implications.

Foon, Y.S., \& Fah, B.C.Y. (2011). Internet banking adoption in Kuala Lumpur: an application of UTAUT model. International Journal of Business and Management, 6, 161.

Gruzd, A., Staves, K., \& Wilk, A. (2012). Connected scholars: Examining the role of social media in research practices of faculty using the UTAUT model. Computers in Human Behavior, 28, 2340-2350. https://doi.org/10.1016/j.chb.2012.07.004

Meske, C., \& Stieglitz, S. (2013). Adoption and Use of Social Media in Small and Medium-Sized Enterprises. 151, 61-75.

Moghavvemi, S., Mohd Salleh, N.A., Zhao, W., \& Mattila, M. (2012). The entrepreneur's perception on information technology innovation adoption: An empirical analysis of the role of precipitating events on usage behavior. Innovation, 14, 231-246. https://doi.org/10.5172/impp.2012.14.2.231

Moghavvemi, S., Salleh, M., Akma, N., Zhao, W., \& Hakimian, F. (2011). An empirical study of IT innovation adoption among small and medium sized enterprises in Klang Valley, Malaysia.

Nysveen, H., \& Pedersen, P.E. (2016). Consumer adoption of RFID-enabled services. Applying an extended UTAUT model. Information Systems Frontiers, 18, 293-314. https://doi.org/10.1007/s10796-014-9531-4

O. P., Putara, H., \& Al.Hasibuan, Z. (2015). E-Business Framework for Small and Medium Enterprises A Critical Review. International Conference on Information, Communication Technology and System.

Pownall, C. (2016). Social Media in Saudi Arabia: More is Less, Less is More? 
Rodrigues, G., Sarabdeen, J., \& Balasubramanian, S. (2016). Factors that Influence Consumer Adoption of E-government Services in the UAE: A UTAUT Model Perspective. Journal of Internet Commerce, 15, 18-39. https://doi.org/10.1080/15332861.2015.1121460

Schaupp, L.C., \& Belanger, F. (2016). Social Commerce Benefits for Small Businesses. Journal of Organizational and End User Computing, 28, 49-66. https://doi.org/10.4018/JOEUC.2016070104

Serben, D.F. (2014). The examination of factors influencing social media usage by African American small business owners using the UTAUT model.

Shokrey, N.M.B.H., Nawi, N.B.C., Nasir, N.A.B.M., \& Al Mamun, A. (2016). Factors contributing to the acceptance of social media as a platform among student entrepreneurs: A review. Mediterranean Journal of Social Sciences, 7,42 .

Sorensen, A.T., \& Shklovski, I. (2011). The Hugging Team: The Role of Technology in Business Networking Practices. In Bodker, S., Bouvin, N.O., Wulf, V., Ciolfi, L., \& Lutters, W. (Eds.), ECSCW 2011: Proceedings of the 12th European Conference on Computer Supported Cooperative Work (September 2011, pp. 24-28). Aarhus Denmark, London: Springer London.

Thomas, C., Petkovich, M., \& Pndya, S. (2014). The examination of factors influencing social media use by african american small business owners using UTAUT model.

Venkatesh, V., Morris, M.G., Davis, G.B., \& Davis, F.D. (2003). User Acceptance of Information Technology: Toward a Unified View. MIS Quarterly, 27, 425-478. https://doi.org/10.2307/30036540

Venkatesh, V., \& Zhang, X. (2010). Unified theory of acceptance and use of technology: US vs. China. Journal of Global Information Technology Management, 13, 5-27. https://doi.org/10.1080/1097198X.2010.10856507

Wamba, S.F., \& Carter, L. (2013). Twitter Adoption and Use by SMEs. An Empirical Study, 2042-2049.

Wamba, S.F., \& Carter, L. (2016). Social Media Tools Adoption and Use by SMEs. Social Media and Networking., Information Resources Management Association Ed., IGI Global, 791-806.

Zhou, T. (2011). Understanding mobile Internet continuance usage from the perspectives of UTAUT and flow. Information Development, 27, 207-218. https://doi.org/10.1177/0266666911414596

Appendix 1

Survey instrument: Questionnaire

For the purpose of this paper, the questionnaire seeks to identify the factors that influence small business entrepreneurs' use of social media. Obtaining feedback from entrepreneurs is vital to a business's improvement. We appreciate your taking the time to complete the following survey. It should take about five minutes of your time. Your responses are voluntary and will be confidential. Responses will not be identified by individual. All responses will be compiled together and analyzed as a group. If you have any questions or concerns, please contact:

\section{* General information:}

Please tick the appropriate answer

\section{Section 1:}

* Do you use social media in your business?

$\circ$ yes

○ no

\section{If yes, please tick the used social media.}

If no, directly continue with section 2 .

- Type of social media used in business:

囚 Twitter

囚 Facebook

囚 Instagram 
$\begin{array}{ll}\text { 凶 } & \text { Snapchat } \\ \text { 凶 } & \text { Path } \\ \text { 凶 } & \text { WhatsApp } \\ \text { 凶 } & \text { Other }\end{array}$

Section 2:

* Gender:

○ Male

- Female

* Age:

- 18 years or less

- 19 to 29

○ 30 to 39

○ 40 to 49

○ 50 to 59

○ 60 or more

\section{* Experience level in using social media:}

○ 12 months or less

○ 13 months to 3 years

○ More than 3 years

* Degree levels:

○ High school or less

- Diploma

○ Bachelor

○ Master

○ $\mathrm{PhD}$

O Other

\section{* Research propose information:}

Please tick one box that matches your view most closely:

Dimension 1. Performance Expectancy (PE)

\begin{tabular}{|c|c|c|c|}
\hline Question & $\begin{array}{ll}\begin{array}{l}\text { Strongly } \\
\text { agree }\end{array} & \text { agree } \\
\end{array}$ & $\begin{array}{l}\text { Neither agree disagree } \\
\text { nor disagree }\end{array}$ & $\begin{array}{l}\text { Strongly } \\
\text { disagree }\end{array}$ \\
\hline $\begin{array}{l}\text { 1- Using social media in my business enables } \\
\text { me to accomplish tasks more effectively. } \\
\text { 2- Using social media networks improves my } \\
\text { job performance. } \\
\text { 3- Using social media networks helps to } \\
\text { improve the quality of customer service. } \\
\text { 4- Overall, I think social media networks are } \\
\text { advantageous to my business. }\end{array}$ & & & \\
\hline
\end{tabular}


Dimension 2. Effort Expectancy (EE)

\begin{tabular}{|c|c|c|c|}
\hline Question & $\begin{array}{l}\text { Strongly agree } \\
\text { agree }\end{array}$ & $\begin{array}{l}\text { Neither agree disagree } \\
\text { nor disagree }\end{array}$ & $\begin{array}{l}\text { Strongly } \\
\text { disagree }\end{array}$ \\
\hline $\begin{array}{l}\text { 1- Learning to use social media networks } \\
\text { was easy for me. } \\
\text { 2- Using social media networks was easy } \\
\text { for me. } \\
\text { 3- I can say that social media networks are } \\
\text { easy to use. } \\
\text { 4- Social media networks are easy to handle } \\
\text { when a problem occurs. }\end{array}$ & & & \\
\hline
\end{tabular}

Dimension 3. Social Influence (SI)

\begin{tabular}{|c|c|c|c|c|}
\hline Question & $\begin{array}{l}\text { Strongly } \\
\text { agree }\end{array}$ & agree & $\begin{array}{l}\text { Neither agree disagree } \\
\text { nor disagree }\end{array}$ & $\begin{array}{l}\text { Strongly } \\
\text { disagree }\end{array}$ \\
\hline 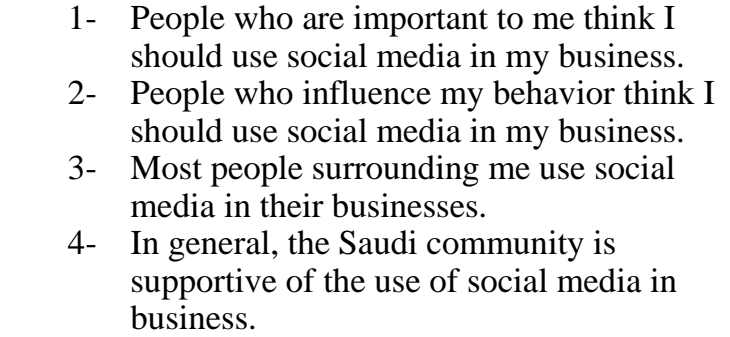 & & & & \\
\hline
\end{tabular}

Dimension 4. Facilitating Conditions (FC)

\begin{tabular}{|c|c|c|c|c|c|}
\hline Question & $\begin{array}{l}\text { Strongly } \\
\text { agree }\end{array}$ & agree & $\begin{array}{l}\text { Neither agree } \\
\text { nor disagree }\end{array}$ & disa & Strongly \\
\hline
\end{tabular}

1- I have the resources necessary to use social media in my business.

2- I have the knowledge necessary to use social media in my business.

3- Social media is compatible with my life.

4- Help is available when I have a problem with using social media in my business.

Dimension 5. Behavioral Intention (BI)

\begin{tabular}{|c|c|c|c|c|c|}
\hline Question & $\begin{array}{l}\text { Strongly } \\
\text { agree }\end{array}$ & agree & $\begin{array}{l}\text { Neither agree } \\
\text { nor disagree }\end{array}$ & $\begin{array}{l}\text { disag } \\
\text { ree }\end{array}$ & $\begin{array}{l}\text { Strongly } \\
\text { disagree }\end{array}$ \\
\hline $\begin{array}{l}\text { 5- I think using social media networks in } \\
\text { my business is essential. } \\
\text { 6- I think using social media networks in } \\
\text { my business is a positive thing to do. } \\
\text { 7- I think using social networks media in } \\
\text { my business is a good idea. }\end{array}$ & & & & & \\
\hline
\end{tabular}

Dimension 6. Behavioral Use (BU)

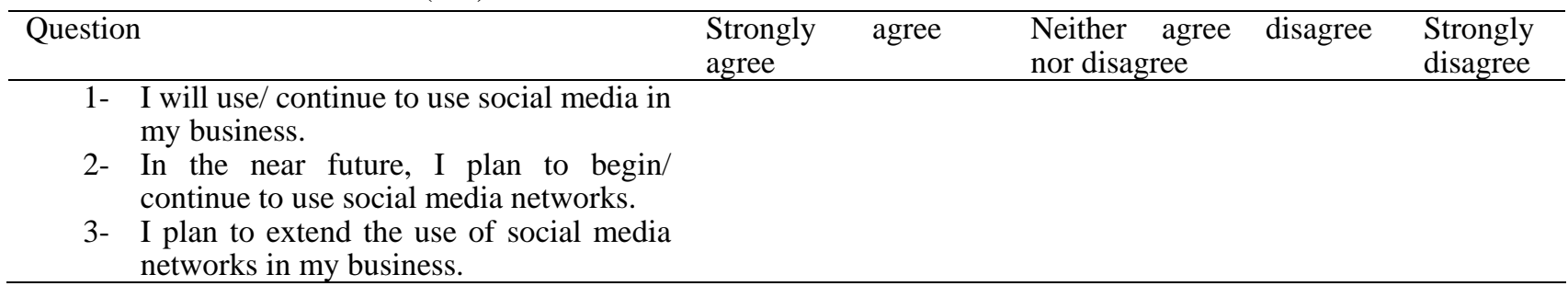

